\title{
Excretion of dissolved organic nitrogen by phytoplankton assessed by wet oxidation and ${ }^{15} \mathrm{~N}$ tracer procedures
}

\author{
Mireille Pujo-Pay*, Pascal Conan, Patrick Raimbault \\ Centre d'Océanologie de Marseille, LOB, Campus de Luminy, Case 901, F-13288 Marseille Cedex 9, France
}

\begin{abstract}
The release of DON in diatom (Phaeodactylum tricornutum) and Chlorophycea (Dunahella tertiolecta) batch cultures was examined by both the wet oxidation procedure and the newly improved ${ }^{15} \mathrm{~N}$ tracer technique for simultaneous isotope-ratio analysis of inorganic and organic forms of nitrogen. Cultures were conducted under different initial nitrate/phosphate ratios and under light and nutrient stressed conditions. Experimental results remamed lower than previous and recent evaluations and showed that less than $10 \%$ of the nitrate uptake was released or excreted as DON.

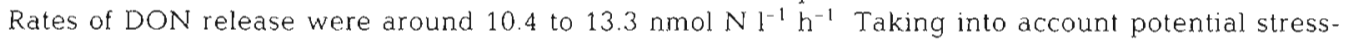
induced DON losses, results tend to confirm that these products were not artefactual and had resulted from phytoplankton excretion. These values of DON release enabled us to completely or nearly completely balance the mitrogen budgets in our experiments. However, since DON originatıng from phytoplankton constitutes an important resource for some organisms, processes other than direct active excretion (such as grazing, cell death or virus infections) must be the main ones leading to significant release of these biodegradable compounds and might explain the high levels of DON release sometimes observed during experimental studies or in the natural environment.
\end{abstract}

KEY WORDS: Phytoplankton excretion Dissolved organic nitrogen Wet oxidation ${ }^{15} \mathrm{~N}$ methodology

\section{INTRODUCTION}

A paradigm of modern oceanography is that the uptake of new nitrogen (new production) by phytoplankton is equal to the upward flux of nitrate into the surface waters, and that this flux is approximately balanced by the flux of particulate nitrogen (PN) out of surface waters over appropriate space and time scales (Eppley \& Peterson 1979). However, during incubation of water samples, nitrogen budgets, expressed as the ratio of the decrease in dissolved inorganic nitrogen (DIN) to the increase in the PN, are frequently unbalanced (Collos 1992, Collos et al. 1992). Generally, more DIN disappears from the medium than cellular nitrogen is produced in the particulate phase. One explanation proposed during the last decade for such discrepancies is the excretion of dissolved organic nitrogen

\footnotetext{
-E-mail: pujopay@com.univ-mrs.fr
}

(DON) (Chan \& Campbell 1978, Laws 1984, Slawyk et al. 1990, Collos 1992, Collos et al. 1992, Bronk \& Glibert 1994). Because of the new implications arising from the inclusion of DON in the traditional paradigm, and also because easily assimilated excreted nitrogen compounds (Sharp 1977) have long been recognized as a nitrogen source of high quality for microheterotrophic organisms (Cole et al. 1982, Azam et al. 1983), this DON pool is increasingly considered in biochemical cycle studies (Hedges et al. 1993, Sharp 1993).

DON comprises a large fraction of the total nitrogen in the marine environment and is present in the whole water column at significant concentrations (generally 2 to $10 \mu \mathrm{M}$ ), even in oceanic waters where dissolved inorganic nitrogen species are undetectable (Sharp 1983). However, despite the large size of this pool and its potential importance as a nitrogen source, relatively little is known about it (Bronk et al. 1994). There is no doubt that some DON can be provided by phytoplank- 
ton. Release of dissolved organic matter during cell death and lysis, during feeding or grazing or even during virus-induced lysis is often evoked in the literature as a source of DON (e.g. Bronk \& Glibert 1993). However, it has been debated for many years whether phytoplankton can excrete DON during its metabolism (Sharp 1977, Aaronson 1978, Lancelot 1983, Obernosterer \& Herndl 1995). In fact, in the past there have been abundant citations of the excretion phenomenon but relatively few direct measurements of it (Sharp 1977). Furthermore, although Yentsch \& Vaccaro had proposed excretion of nitrogen compounds as early as 1958, little work has been carried out on DON since then. Most available information on this pool has been derived from studies on individual components of DON, such as amino acids (Wheeler \& Kirchman 1986, Fuhrman 1987. Antia et al. 1991, Jørgensen et al 1993), urea (McCarthy et al. 1977, Turley 1985, 1986 Hansell \& Goering 1989) and DNA (Paul et al. 1987), or extrapolated from studies of dissolved organic carbon flux (Glibert \& Bronk 1994).

Recent studies on DON indicate that significant excretion could take place during cellular rycles but it would be often masked by non-adapted sampling (Collos 1992) During the experiment conducted by Collos et al. (1992) on a unicellular culture of Synedra planctonica, the DON concentrations of the culture medium, after being entirely absorbed during a dark incubation period of $24 \mathrm{~h}$, increased from undetectable values to $30 \mu \mathrm{M}$ after $4 \mathrm{~h}$ of light (where the initial cell. concentration was $4 \times 10^{5}$ cell $\mathrm{ml}^{-1}$ and nitrate was $\sim 200 \mu \mathrm{M}$ ). Other investigations indicate that excreted or released DON could in fact represent up to $63-75 \%$ of nitrate or DIN uptake (Collos 1992, Collos et al. 1992) and 11 to $74 \%$ of the DIN (ammonia and nitrate) taken up by phytoplankton in oceanic, coastal and estuarine environments (Bronk et al. 1994). Thus, these high levels of released DON could be very important in oceanic nitrogen budgets. The DON excreted could effectively account for 90 to $100 \%$ of the missing nitrogen generally observed in the final nitrogen budget (Collos 1992) and fulfil the discrepancy generally observed between gross and net uptake rates (Bronk et al. 1994).

Improvement of analytical techniques and the awareness of possible procedural artefacts allow a reduction in uncertainties about results. In this way, the simultaneous application of the chemical wet oxidation (Pujo-Pay \& Raimbault 1994) and the new ${ }^{15} \mathrm{~N}$ tracer technique (Slawyk \& Raimbault 1995) procedures allowed us, in a very simple manner, to follow the DIN uptake rate and the subsequent release of DON (and DO ${ }^{15} \mathrm{~N}$ ) during the phytoplanktonic growth (measured by changes in the particulate nitrogen concentrations) of unicellular algae (Phaeodactylum tricor- nutum and Dunaliella tertiolecta). Experiments were conducted during light and dark periods and under different nutrient conditions (different nitrate/phosphate ratio: $\mathrm{NO}_{3} / \mathrm{PO}_{4}$ ). We wanted to test the effect, on the DON excretion, of $\mathrm{NO}_{3} / \mathrm{PO}_{4}$ greater than the conventional Redfield ratio of 16 (Redfield 1958), reflecting conditions of phosphate limitation classically found in the Mediterranean Sea (Berland et al. 1980). As nitrate is generally considered to be the limiting factor of the phytoplanktonic production (Thomas 1966 , Ryther \& Dunstan 1971, Eppley et al. 1973, Goldman et al. 1979, Howarth \& Cole 1985, Codispoti 1989), we also wanted to study DON excretion in media with $\mathrm{NO}_{3} / \mathrm{PO}_{4}$ lower than 16 (conditions of nitrate limitation). In the same way as Collos et al. (1992) we maintained our cultures in the dark for $24 \mathrm{~h}$ to investigate effects of prolonged darkness on DON evolution. We also carried out a perturbation experiment by using a substantial $\mathrm{NO}_{3}$ enrichment $\left(\mathrm{NO}_{3} / \mathrm{PO}_{4}>300\right)$ in the culture medium to see if algae were able to excrete DON absorbed as DIN. Furthermore, we evaluated potential 'artefactual' release of DON during filtration by minimising, as much as possible, the eventual cell breakages to obtain a filtered sample where the DON concentrations were compared with those contained in. samples classically filtered.

Here we aim to examine and quantify DON production from phytoplankton cultures by applying the new analytical techniques in experiments taking into account potential stress-induced DON losses.

\section{MATERIALS AND METHODS}

Experimental procedure. To investigate DON excretion by phytoplankton, we followed the growth of 2 algal species in axenic batch cultures under different nitrate/phosphate $\left(\mathrm{NO}_{3} / \mathrm{PO}_{4}\right)$ ratio conditions. During the algal growth, monitored by cell density and concentrations of particulate nitrogen (PN) and phosphorus (PP), nutrient uptake and dissolved organic nitrogen (DON) evolution were measured. To compare nitrogen budgets obtained with chemical measurements, one of the cultures (culture $15-\mathrm{N}$ ) was carried out with labelled nitrate $\left({ }^{15} \mathrm{NO}_{3}\right)$. This allowed us to follow the transfer of the ${ }^{15} \mathrm{~N}$ isotope from the mineral $\left(\mathrm{NO}_{3}\right)$ to the other nitrogen fractions (especially in DON). Then, changes in DON concentrations were investigated when these cultures were maintained in darkness (darkness period), and submitted to severe nutrient disequilibrium (perturbation experiment). Finally, as DON concentrations were generally determined in filtered samples, an experiment was carried out to evaluate possible DON release due to mechanical cellular stresses. 
Phytoplankton cultures. Stock cultures of the diatom Phaeodactylum tricornutum (Bohlin 1897) and the chlorophycean Dunaliella tertiolecta (Butcher 1952) were used. The P. tricornutum clone was originally isolated from the Gulf of Lions (Mediterranean Sea) by B. Berland and came from the culture collection of the 'Centre d'Océanologie de Marseille' (France). The D tertiolecta stock originated from the clone PLY 83 of the Plymouth Marine Laboratory (UK) culture collection. Stocks were maintained in $f / 2$ medium (Guillard \& Ryther 1962) and submitted to antibiotic treatments and subcultured regularly (sterile conditions) so that they remained axenic. To make the experimental batch phytoplankton cultures, each stock species was then subcultured into new media of 5 or 61 volume, prepared with natural nutrient-poor surface seawater collected from the Mediterranean Sea (oligotrophic area) and filtered through $0.2 \mu \mathrm{m}$ Sartorius filters. These new media were an amended version of $f / 2$ medium (with defined concentrations of trace metals and vitamins) with different $\mathrm{NO}_{3} / \mathrm{PO}_{4}$ ratios. These axenic cultures were continuously stirred and were maintained in Pyrex flasks at $17^{\circ} \mathrm{C}$ on $12: 12 \mathrm{~h}$ light. dark cycles (irradiance: 135 to $150 \mu \mathrm{E} \mathrm{m} \mathrm{m}^{-2} \mathrm{~s}^{-1}$ ). Sampling was performed throughout by slowly siphoning aliquots through a Teflon tube placed in the cultures.

Initially, one culture (5 l) for each species was made (with nitrate-limiting conditions and an initial $\mathrm{NO}_{3} /$ $\mathrm{PO}_{4}$ ratio lower than 16 ). The culture of Dunaliella tertiolecta is referred to as 'culture 1 ' and the Phaeodactylum tricornutum as 'culture 15- $\mathrm{N}$ ' (according to its ${ }^{15} \mathrm{~N}-\mathrm{NO}_{3}$ enrichment, see below). Then, in order to test different nutrient conditions, 5 cultures (6 1) were prepared for each species with initial $\mathrm{NO}_{3} / \mathrm{PO}_{4}$ ratios close to $2,4.5,9,13$ and 20 and are referred to respectively as $\mathrm{A}, \mathrm{B}, \mathrm{C}, \mathrm{D}$ and $\mathrm{E}$. Initial $\mathrm{NO}_{3}$ and $\mathrm{PO}_{4}$ concentrations for all these cultures are shown in Table 1.

Parameters studied. Concentrations of dissolved inorganic nutrients, DON and biomass (as cell number, particulate nitrogen and phosphorus) were followed over the course of 4 to $7 \mathrm{~d}$. Samples were collected once or twice per day for culture 1 and culture $15-\mathrm{N}$, and at the beginning $\left(T_{0}\right)$, after $3 \mathrm{~d}$ and at the end of the experiment for cultures A, B, C, D and E. Individual samples were taken and analysed for each of the parameters under investigation. Duplicate samples were occasionally removed to ensure reproducibility of the sampling/analyses. To verify that media remained axenic, some culture samples were observed by image- analysed epifluorescence microscopy (Van Wambeke 1988).

Biomass: Cell density was determined by optical microscopy and particulate nitrogen (PN) and phosphorus (PP) concentrations were determined simultaneously according to the wet oxidation procedure of Pujo-Pay \& Raimbault (1994). The particulate matter was collected by filtration (under low vacuum, $<50 \mathrm{~mm}$ $\mathrm{Hg}$ ) of a culture sample onto a pre-combusted $(4 \mathrm{~h}$, $450^{\circ} \mathrm{C}$ ) GF/F glass fibre filter (25 $\mathrm{mm}$ diam.).

Nutrient uptake: Nitrate+nitrite $\left(\mathrm{NO}_{3}\right)$ and phosphate $\left(\mathrm{PO}_{4}\right)$ uptakes were estimated by measuring these nutrient concentrations with an automated colorimetric technique on a Technicon Auto-Analyzer (Tréguer \& Le Corre 1975). Nitrate uptake was evaluated with the isotopic $\left({ }^{15} \mathrm{~N}\right)$ method in culture $15-\mathrm{N}$. This culture prepared using $100 \%{ }^{15} \mathrm{~N}$-labelled nitrate (39.4 $\mu \mathrm{M}$ of ${ }^{15} \mathrm{~N}-\mathrm{NO}_{3}$ and with $\mathrm{NO}_{3} / \mathrm{PO}_{4}=9$; Table 1). At the end of the exponential growth phase, a sample of $10 \mathrm{ml}$ was filtered onto a GF/F filter and the ${ }^{15} \mathrm{~N}$ atom enrichment in the particulate nitrogen pool (resulting from the ${ }^{15} \mathrm{~N}-\mathrm{NO}_{3}$ uptake) was determined using a mass spectrometer.

Concentrations of ammonia $\left(\mathrm{NH}_{4}\right)$ were believed to be negligible in the culture media because of the oligotrophic origin of the seawater used. However, to confirm this assertion, measurements were made (according to Koroleff 1969) at the beginning, middle and end of each experiment.

Dissolved organic nitrogen: Generally, DON concentrations $( \pm 0.1 \mu \mathrm{M})$ were determined from filtered samples. However, in culture 15-N, DON concentrations were determined from both (1) filtered and (2) unfiltered samples to compare both types of evaluations:

Table 1. Initial $\left(T_{0}\right)$ nitrate+nitrite $\left(\mathrm{NO}_{3}\right)$ and phosphate $\left(\mathrm{PO}_{4}\right)$ concentrations and $\mathrm{NO}_{3} / \mathrm{PO}_{4}$ ratios in the different studied cultures: Culture 1 of Dunaliella tertiolecta, culture 15-N of Phaeodactylum tricornutum and cultures of both species with different nutrient conditions referred to as A, B, C, D and E

\begin{tabular}{|llccc|}
\hline Culture & Species & $\mathrm{NO}_{3}(\mu \mathrm{M})$ & $\mathrm{PO}_{4}(\mu \mathrm{M})$ & $\mathrm{NO}_{3} / \mathrm{PO}_{4}$ \\
\hline Culture 1 & Dunaliella tertiolecta & 40.7 & 5.8 & 7.0 \\
Culture 15-N & Phaeodactylum tricornutum & 39.4 & 4.4 & 9.0 \\
A & Phaeodactylum tricornutum & 20.1 & 1.0 & 20 \\
$\mathrm{~B}$ & Phaeodactylum tricornutum & 20.2 & 1.6 & 13 \\
$\mathrm{C}$ & Phaeodactylum tricornutum & 19.5 & 2.1 & 9 \\
D & Phaeodactylum tricornutum & 19.3 & 4.3 & 4.5 \\
$\mathrm{E}$ & Phaeodactylum tricornutum & 19.1 & 8.5 & 2 \\
$\mathrm{~A}$ & Dunaliella tertiolecta & 20.0 & 1.0 & 20 \\
$\mathrm{~B}$ & Dunaliella tertiolecta & 20.0 & 1.5 & 13 \\
$\mathrm{C}$ & Dunaliella tertiolecta & 19.5 & 2.1 & 9 \\
$\mathrm{D}$ & Dunaliella tertiolecta & 19.5 & 4.3 & 4.5 \\
$\mathrm{E}$ & Dunaliella tertiolecta & 19.3 & 8.0 & 2 \\
\hline
\end{tabular}


(1) DON was obtained from oxidation of filtered samples (FN) (used for the PN determination) corrected for their nitrate+nitrite $\left(\mathrm{NO}_{3}\right)$ concentrations, $\mathrm{DON}=\mathrm{FN}-$ $\mathrm{NO}_{3}$.

(2) DON was obtained from oxidation of total samples (TN) corrected for their particulate nitrogen (PN) and nitrate+nitrite $\left(\mathrm{NO}_{3}\right)$ concentrations, $\mathrm{DON}=\mathrm{TN}-$ $\mathrm{PN}-\mathrm{NO}_{3}$.

Samples $(20 \mathrm{ml}$ of $\mathrm{FN}$ and $\mathrm{TN})$ were directly collected in Teflon bottles. The procedure used for particulate nitrogen was used for DON determination (full details given in Pujo-Pay \& Raimbault 1994, Pujo-Pay 1995). Samples were oxidized with $2.5 \mathrm{ml}$ of reagent $\left(30 \mathrm{~min}, 120^{\circ} \mathrm{C}\right)$ and nitrate+nitrite determinations were performed on a Technicon Auto-Analyzer.

Nitrogen budget obtained from isotopic measurements: In culture 15- $\mathrm{N}$ containing the labelled nitrate, the procedure recently described by Slawyk \& Raimbault (1995) was used and allowed simultaneous isotope-ratio analysis of inorganic (DIN $=\mathrm{NO}_{3}+\mathrm{NO}_{2}+$ $\mathrm{NH}_{4}$ ) and organic (DON) forms of nitrogen extracted from seawater samples. Thus we could determined if labelled nitrogen entered the DON pool (i.e. whether labelled nitrate could be excreted/released as labelled DON). At the end of the incubation period (160 h), $300 \mathrm{ml}$ of the culture medium was filtered $1<50 \mathrm{~mm}$ $\mathrm{Hg}$ ) through a Whatman $\mathrm{GF} / \mathrm{F}$ filter. The filtrate was used to determine firstly the ${ }^{15} \mathrm{~N}$ enrichment in the DIN and secondly that of the DON (Slawyk \& Raimbault 1995)

After these experiments were completed, the entire set of cultures A, B, C, D and E was used successively in 2 additional experiments, one designed to examine DON production in exponentially growing cells in the dark, and the other designed to examine DON production in starved cells after a nutrient pulse (perturbation experiment). For the latter experiment, the previous culture 1 of Dunaliella tertiolecta and a new culture of Phaeodactylum tricornutum were also used.

Darkness period. DON changes under prolonged darkness were investigated in cultures $A, B, C, D$ and $E$ after algae were allowed a new cycle of cell divisions. At the end of their first exponential growth (during the stationary phase of culture in the experiment described above), cultures were diluted 1:1 (same dilution ratio for all the cultures) with fresh $\mathrm{f} / 2$ medium. Algae were then incubated for $24 \mathrm{~h}$ (12:12 h light:dark cycle). To maintain the algae in an exponential growth phase, cultures were diluted and incubated a second time under the same conditions (same dilution ratio and light:dark period). Cultures were then maintained in darkness for $24 \mathrm{~h}$. DON concentrations were measured before and after this $24 \mathrm{~h}$ darkness period.

Perturbation experiment. In the last part of our experimental procedure, we followed the time course
Table 2. Nitrate+nitrite $\left(\mathrm{NO}_{3}\right)$ concentrations and $\mathrm{NO}_{3} / \mathrm{PO}_{4}$ ratios medsured immediately after the nitrate enrichment of the cultures (culture 1, culture 15- $N$ and cultures $A, B, C, D$ and $E$ ) at the end of their exponential growth, during the perturbation experiment

\begin{tabular}{|lcccc|}
\hline Culture & $\begin{array}{c}\text { Phaeodactylum } \\
\text { tncornutum } \\
\mathrm{NO}_{3}(\mu \mathrm{M})\end{array}$ & $\mathrm{NO}_{3} / \mathrm{PO}_{4}$ & $\begin{array}{c}\text { Dunaliella } \\
\text { tertiolecta } \\
\mathrm{NO}_{3}(\mu \mathrm{M})\end{array}$ & $\mathrm{NO}_{3} / \mathrm{PO}_{4}$ \\
\hline New culture & 40.1 & 334 & & \\
Culture 1 & & & 32.2 & 403 \\
$\mathrm{~A}$ & 16.9 & 359 & 26.6 & 739 \\
$\mathrm{~B}$ & 15.5 & 444 & 26.0 & 542 \\
$\mathrm{C}$ & 15.0 & 654 & 26.0 & 2166 \\
$\mathrm{D}$ & 24.2 & 1053 & 26.1 & 1449 \\
$\mathrm{E}$ & 24.1 & 19 & 22.9 & 8 \\
\hline
\end{tabular}

of DON through excretion when cultures were submitted to severe nutrient disequilibrium at the end of their exponential growth. For this perturbation experiment, we again used the cultures $A, B, C, D$ and $E$ (after the darkness experiment). We also used the previous culture 1 of Dunaliella tertiolecta and another culture of Phaeodactylum tricornutum referred to as 'new culture' (that had initially been grown simultaneously with the culture $15-\mathrm{N}$ ). For this new culture, the time course of some parameters $\left(\mathrm{NO}_{3}, \mathrm{TN}, \mathrm{PN}, \mathrm{DONf}\right)$ in the culture before this perturbation experiment is shown in Fig $2 a$.

At the end of the exponential phytoplanktonic growth phase (when $\mathrm{PO}_{4}$ concentrations were approximately zero), a single addition of nitrate was made to the culture media. Cultures were enriched with nitrate to provide the concentrations shown in Table 2 $\left(\mathrm{NO}_{3} / \mathrm{PO}_{4}\right.$ ratio higher than 300$)$. $\mathrm{NO}_{3}$ uptake was monitored during the light phase at approximately 60 to 120 min intervals until exhaustion of nitrate from the medium. DON concentrations were determined just after $\mathrm{NO}_{3}$ enrichment $\left(T_{0}\right)$ for all the cultures, and after nitrate exhaustion for culture 15-N (at $T_{7 \mathrm{~h}}$ and $T_{8 \mathrm{~h}}$ ) and the new culture (at $T_{4 \mathrm{~h}}$ and $T_{6 \mathrm{~h} 30}$ ), and at various times ( $\leq 3 \mathrm{~h}$ ) in cultures $\mathrm{A}, \mathrm{B}, \mathrm{C}, \mathrm{D}$ and $\mathrm{E}$.

Release of DON during filtration. Finally, another experiment was conducted to verify that the measured DON production was not an experimental artifact resulting from filtration. In this experiment, 5 I cultures ( 2 cultures prepared with $\mathrm{f} / 2$ medium ) were inoculated with the initial stock cultures of each algal species. Each culture was incubated under the conditions described above and DON production monitored by sampling using 2 different approaches. The first approach was the same technique used in the other experiments (i.e. a subaliquot was removed and filtered to remove phytoplankton cells, DON was the organic nitrogen which passed through the filters). In 
the second approach, filtration was avoided through samples being collected from the inside of a 'sampling bag' placed into the culture. The sampling bag was made of Nuclepore polycarbonate membrane $11 \mu \mathrm{m}$ pore size) which permitted only the culture medium to enter the bag. This provided a passive means of obtaining cell-free material in which the DON could not have been produced by cell breakage during filtration of the sample. DON concentrations resulting from the 2 sampling techniques were then compared. Samples from inside the Nuclepore bag were regularly checked by microscopy to verify the absence of algal cells.

\section{RESULTS}

\section{Characteristics of the algal growth}

Similar results were obtained for both species in all the cultures (culture 1, culture 15-N, and cultures A, B, C, D and E). Observations of culture samples by epifluorescence microscopy did not reveal the presence of any heterotrophic organisms (ciliates or bacteria) and cultures remained axenic during the experiment. Time courses of the studied parameters in cultures are shown in Fig. 1 for Phaeodactylum tricornutum and Dunaliella tertiolecta. The complete data set is pre-
Phaeodactylum tricornutum

15-N culture
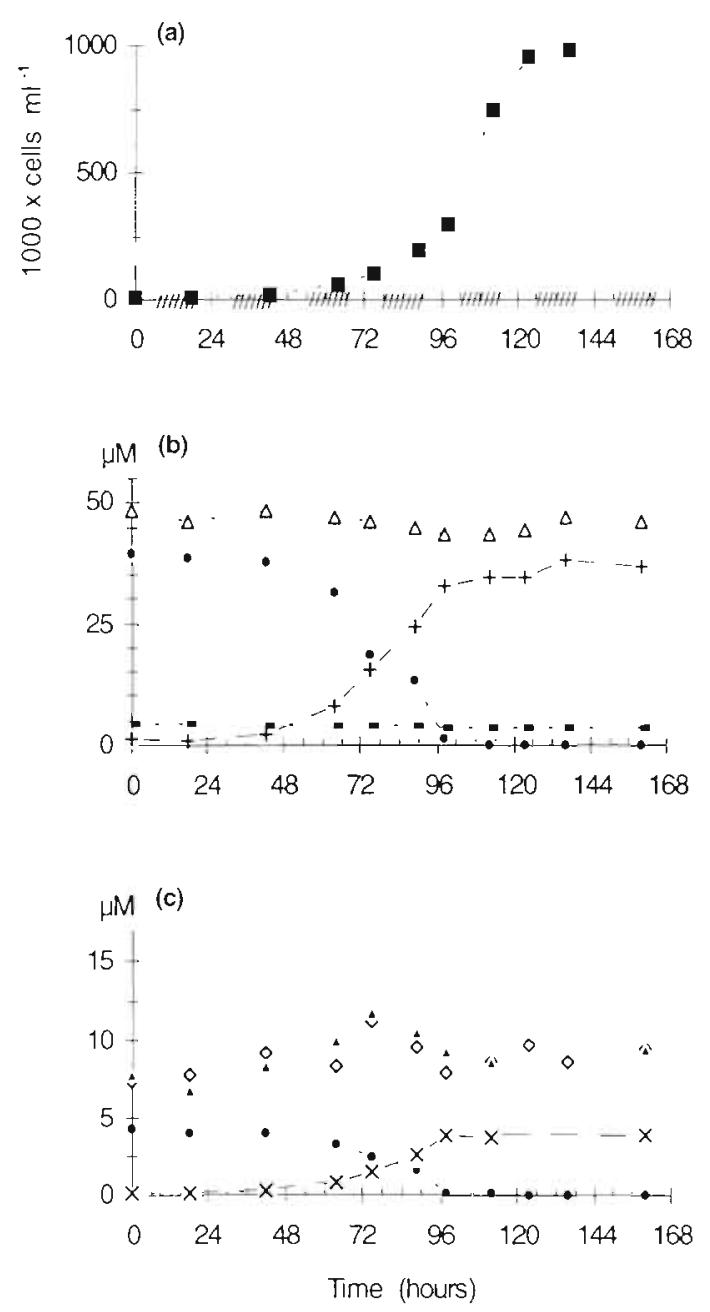

\section{Dunaliella tertiolecta}

Culture 1
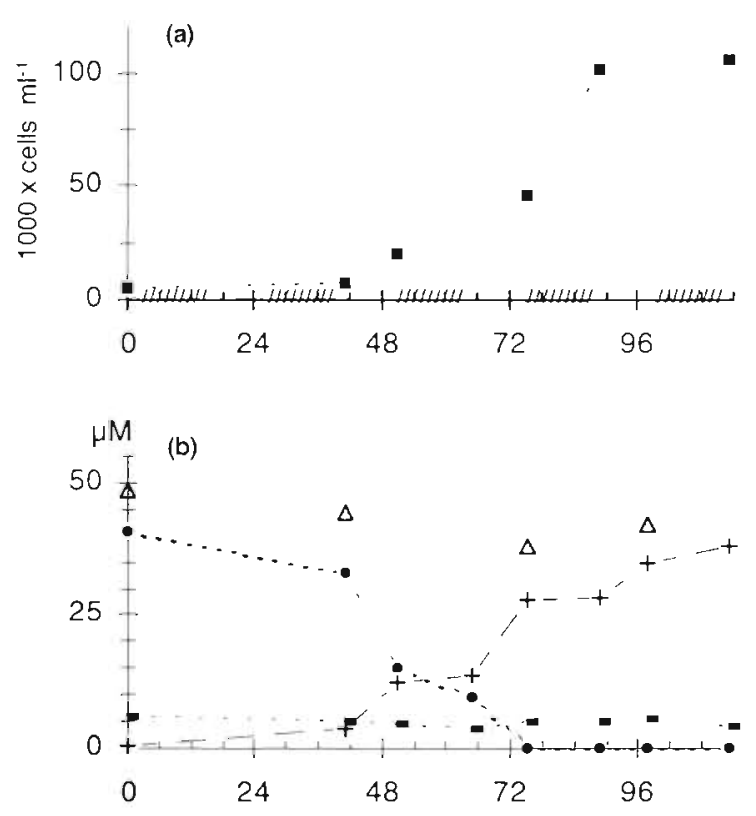

(c)

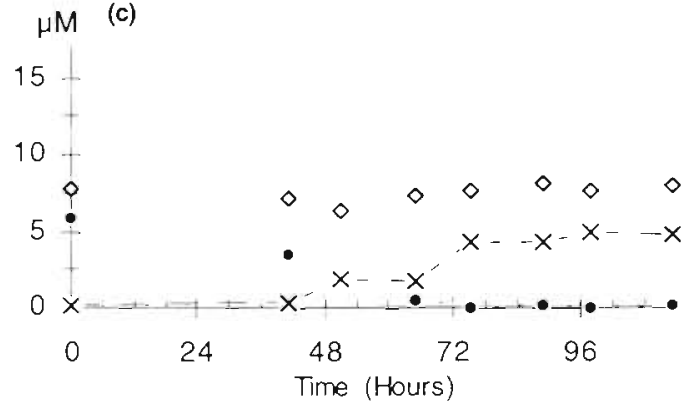

Fig. 1 Time course of the concentrations of the parameters studied dunng the algal growth of Phaeodactylum tricornutum (culture 15-N) and Dunaliella tertholecta (culture 1). (a) Cell concentratıons. Hatching on tıme axis represents dark periods. (b) Nitrate+nitrite $\left(\mathrm{NO}_{3}\right.$ ), particulate nitrogen ( $\mathrm{PN}$ ), total nitrogen and phosphorus (TN and TP). (c) Phosphate (PO 4$)$, particulate phosphorus (PP) and dissolved organic nitrogen referred to as DONC for dissolved organic nitrogen determined from the total fraction (TN) (DONC = TN $-\mathrm{PN}-\mathrm{NO}_{3}$ ) and DONf for dissolved organic nitrogen determined from the filtered sample (FN) 
Table 3. Differences of DON concentrations $(\triangle D O N)$ between the beginning $\left\{T_{0}\right\}$ and the end $\left(T_{96 h}\right.$ for Phaeodactylum tricornutum and $T_{125 \mathrm{~h}}$ for Dunalsella tertiolecta species) of the incubation of cultures $\mathrm{A}, \mathrm{B}, \mathrm{C}, \mathrm{D}$ and $\mathrm{E}$ with different initial $\mathrm{NO}_{3} / \mathrm{PO}_{4}$ ratios (initial ratios of $2,4.5,9,13$ and 20 respectively)

\begin{tabular}{|c|c|c|c|c|c|c|}
\hline \multirow[t]{2}{*}{ Culture } & \multicolumn{3}{|c|}{$\begin{array}{c}\text { Phaeodactylum } \\
\text { tricornutum }\end{array}$} & \multicolumn{3}{|c|}{$\begin{array}{l}\text { Dunaliella } \\
\text { tertiolecta }\end{array}$} \\
\hline & $T_{0}$ & $T_{96 j\}}$ & $\triangle \mathrm{DON}$ & $T_{0}$ & $T_{125 k}$ & $\triangle D O N$ \\
\hline A & 9.74 & 7.89 & 1.85 & 8.49 & 8.11 & 0.38 \\
\hline B & 9.87 & 8.17 & 1.70 & 8.37 & 8.33 & 0.04 \\
\hline C & 9.36 & 7.53 & 1.83 & 8.38 & 7.52 & 0.86 \\
\hline$D$ & 8.49 & 7.72 & 0.77 & 10.21 & 8.15 & 2.06 \\
\hline $\mathrm{E}$ & 8.31 & 9.26 & 0.95 & 8.92 & 7.43 & 1.49 \\
\hline
\end{tabular}

sented for culture 1 and culture $15-N$. For cultures $A$, $B, C, D$ and $E$, variations of DON concentrations between the beginning and the end of the incubations are shown in Table 3. Fig. 1 shows the concentrations over time of algal cells, nitrate+nitrite $\left(\mathrm{NO}_{3}\right)$, phosphate $\left(\mathrm{PO}_{4}\right)$, total nitrogen (TN) and phosphorus (TP), particulate and dissolved organic nitrogen (PN and DON) and phosphorus (PP and DOP).

\section{Total nitrogen and phosphorus}

Total nitrogen (TN) and phosphorus (TP) concentrations generally remained steady. However, it is notable that reductions in these fractions were sometimes observed. For example, in culture $15-\mathrm{N}$, between the beginning and the end of the experiment, there was a decrease around $2 \mu \mathrm{M}$ of TN and $0.56 \mu \mathrm{M}$ of TP

\section{Dissolved inorganic nitrogen (DIN), DON} concentrations and phytoplanktonic growth

As we had hypothesized, the concentrations of ammonia remained quite low $(<0.4 \mu \mathrm{M})$ in all cultures during the whole experiment. While ambient nutrient concentrations $\left(\mathrm{NO}_{3}, \mathrm{PO}_{4}\right)$ decreased continuously down to undetectable levels after 3 or $6 \mathrm{~d}$ of incubation, there was an increase of the algal biomass indicated by the cell density and particulate nitrogen and phosphorus concentrations (Fig. 1a, b, c). Curves showed a 'classic' time course of unicellular organism growth (Fogg 1965) with a maximum biomass up to 200 times more (culture 15-N) than initial cell concentrations (Fig. 1a) and with a stabilisation near 0.02 to $0.03 \mathrm{pmol}^{\mathrm{PN}} \mathrm{cell}^{-1}$ and $0.004 \mathrm{pmol}^{\mathrm{PP}} \mathrm{cell}^{-1}$ for Phaeodactylum tricornutum and 0.03 pmol PN cell ${ }^{-1}$ and 0.03 pmol PP cell ${ }^{-1}$ for Dunaliella tertiolecta species

Concentrations of dissolved organic phosphorus, de-
Table 4. Quantities of labelled nitrogen $\left(\mu \mathrm{M}^{15} \mathrm{~N}\right)$ in the particulate (PN), dissolved inorganic nitrogen. (DIN = nitrate+ nitrite) and dissolved organic nitrogen (DON) pool at the end of the incubation of culture 15-N (Phaeodactylum tricornutum enriched with ${ }^{15} \mathrm{~N}-\mathrm{NO}$

\begin{tabular}{|cc|}
\hline Pool & $\mu \mathrm{M}^{15} \mathrm{~N}$ \\
\hline PN & 37.8 \\
DIN & 0.099 \\
DON & 1.53 \\
\hline
\end{tabular}

termined simultaneously with DON, remained below $0.05 \mu \mathrm{M}$ in all cultures. DON concentrations obtained from filtered $\left(\mathrm{DON}=\mathrm{FN}-\mathrm{NO}_{3}\right)$ and nonfiltered $(\mathrm{DON}$ $=\mathrm{TN}-\mathrm{PN}-\mathrm{NO}_{3}$ ) samples were very close (Fig. 1C). They showed some fluctuations ( $<5 \mu \mathrm{M})$ during the experiments and finally, between the beginning and the end of the incubation, there was an increase of DON concentrations of around $1.67 \mu \mathrm{M}$ (between $T_{0}$ and $T_{160 \mathrm{~h}}$ ) in culture $15-\mathrm{N}$, and $0.46 \mu \mathrm{M}$ (between $T_{0}$ and $T_{113 \mathrm{~h}}$ ) in culture 1 . In cultures $\mathrm{A}, \mathrm{B}, \mathrm{C}, \mathrm{D}$ and $\mathrm{E}_{1}$ variations of DON concentrations between the beginning $\left(T_{0}\right)$ and the end of the incubations ( $T_{96 \mathrm{~h}}$ for Phaeodactylum tricornutum and $T_{125 \mathrm{~h}}$ for Dunaliella tertiolecta) remained between $0.04 \mu \mathrm{M}$ and $2.1 \mu \mathrm{M}$ for the 2 algal species (Table 3). The different initial $\mathrm{NO}_{3} / \mathrm{PO}_{4}$ ratios (of $2,4.5,9,13$ and 20 respectively) did not have a significant influence on the phytoplanktonic DON release.

\section{Isotopic analyses and nitrogen budgets}

Concentrations of labelled nitrogen in DIN, and particulate and dissolved organic fractions at the end of the incubation of the culture $15-\mathrm{N}$ enriched with ${ }^{15} \mathrm{~N}$ $\mathrm{NO}_{3}$ are presented in Table 4 . Results show that inorganic nitrogen initially added in the culture $(39.34 \mu \mathrm{M}$ of ${ }^{15} \mathrm{~N}-\mathrm{NO}_{3}$ ) was incorporated in the particulate and dissolved organic fractions that were both ${ }^{15} \mathrm{~N}$ enriched. 'Chemical' ( $\mathrm{NO}_{3}$ and organic nitrogen determination by wet oxidation) and 'isotopic' budgets were determined between the beginning $\left(T_{0}\right)$ and the end of the incubation $\left(T_{160 h}\right)$ (Table 5 ).

The chemical budget showed that $90.6 \%$ of the $\mathrm{NO}_{3}$ which disappeared from the medium was recovered in the particulate nitrogen fraction while $4.2 \%$ was recovered in the DON pool. However there was an apparent loss of total nitrogen (TN) of around $2 \mu \mathrm{M}$ $(-5 \%)$. The ${ }^{15} \mathrm{~N}$ isotopic budget was well balanced and $37.8 \mu \mathrm{M}$ of the initial ${ }^{15} \mathrm{~N}$ (equivalent to $96.3 \%$ of the labelled $\mathrm{NO}_{3}$ uptake) was incorporated into the particulate nitrogen (PN) fraction while $1.53 \mu \mathrm{M}$ (equivalent to $3.9 \%$ of the labelled $\mathrm{NO}_{3}$ uptake) was incorporated into the DON pool. 
Table 5. Nitrogen budgets $(\mu \mathrm{M})$ determined by wet oxidation (chemical) and isotopic $\left({ }^{15} \mathrm{~N}\right)$ techniques. $\Delta x$ is the difference between untial $\left(T_{0}\right)$ and final $\left(T_{150 h}\right)$ concentration of the element $x$ in the culture. $x \%$ is the percentage of this quantity $x$ related to the inorganic substrate uptake $\left(\Delta \mathrm{NO}_{3}\right.$ where $\mathrm{NO}_{3}=$ nitrate+nitrite $)$

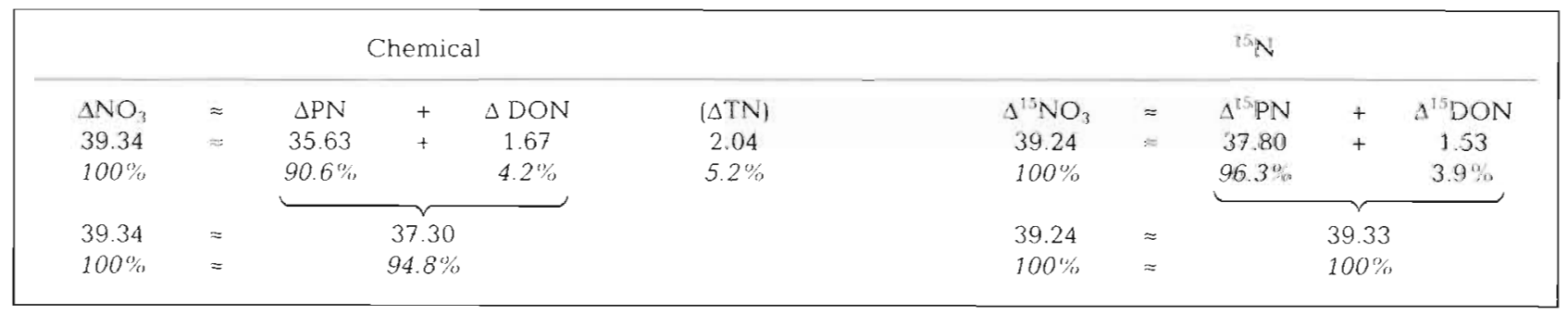

Table 6. Concentrations of DON before $\left(T_{0}\right)$ and after $\left(T_{24}\right)$ the 24 h darkness incubation period of cultures $A, B, C, D$ and $E$ of Phaeodactylum tricornutum and Dunaliella tertiolecta. At

$T_{0}$, cultures were in early exponential growth phase

\begin{tabular}{|c|c|c|c|c|}
\hline \multirow[t]{2}{*}{ Culture } & \multicolumn{2}{|c|}{$\begin{array}{c}\text { Phaeodactylum } \\
\text { tricornutum }\end{array}$} & \multicolumn{2}{|c|}{$\begin{array}{l}\text { Dunaliella } \\
\text { tertiolecta }\end{array}$} \\
\hline & $T_{0}$ & $T_{24}$ & $T_{0}$ & $T_{24}$ \\
\hline A & - & - & 8.11 & 7.96 \\
\hline B & 7.17 & 6.98 & 8.33 & 9.73 \\
\hline C & 7.53 & 9.43 & 7.52 & 8.41 \\
\hline D & 7.72 & 6.60 & 8.15 & 8.32 \\
\hline$E$ & 9.26 & 7.05 & - & - \\
\hline
\end{tabular}

\section{Incubation of cultures in darkness}

After the re-incubation of the cultures A, B, C, D and $E$ (in active growth phase) had been prolonged for $24 \mathrm{~h}$ in darkness, chemical measurements did not show any more variation of DON concentrations than in the investigation of DON changes during 'classical' growth (under 12:12 h light:dark cycles). Comparisons between DON concentrations before and after this $24 \mathrm{~h}$ darkness period showed variations remaining between 0.04 and $2 \mu \mathrm{M}$ DON (Table 6). In any case, there was neither a decrease of DON concentrations that allowed DON concentrations to reach $0 \mu \mathrm{M}$ in the culture, as observed in the experiment of Collos et al. (1992), nor an excretion after this dark period, when cultures were illuminated again during the perturbation experiment (see below in Fig. 2, the initial DON concentrations in the cultures used for the perturbation experiment).

\section{Perturbation experiment}

In another part of our experimental strategy, DON was followed in cultures submitted to severe nutrient disequilibrium. Enrichment of $\mathrm{NO}_{3}$ was made after the exponential growth, during the stationary phase, at
$T_{114 h}$ of the algal growth shown in Fig. 1 (first part of the experiment) for culture 1 of Dunaliella tertiolecta, at $T_{210 \mathrm{~h}}$ of the algal growth shown in Fig. $2 \mathrm{a}$ for the new culture of Phaeodactylum tricornutum, and after the darkness period described above for cultures A, B, C, $D$ and $E$. When we added this high quantity of nitrate (15 to $40 \mu \mathrm{M}$ ) to the cultures, nitrate uptake occurred rapidly and concentrations became undetectable around 4 to $8 \mathrm{~h}$ after the enrichment (Fig. 2). This perturbation did not induce a significant increase of DON concentrations during the course of the experiment in any the cultures of the 2 phytoplanktonic species.

\section{Artificial release of DON during filtration}

We investigated possible DON losses through potential stress during the classical filtration of the culture samples with the help of what we referred to as a 'sampling-bag'. However, there were no significant differences between concentrations of DON determined from samples taken inside the bag (DON1) and samples filtered onto GF/F filters (DON2) as previously described (Table 7 )

\section{DISCUSSION}

Algae in these experiments used inorganic substrates and followed the time-lag between DIN uptake (and assimilation) and algal division (Fig 1) as has been previously observed by Kofoid (1903). It is a classical phenomenon, both during culture experiments and in the natural marine environment (Collos 1986 , Duarte 1990). Similarly, batch culture models show that algal assimilation of the substrate ended well before the cessation of growth (Grenney et al. 1973. Droop 1974, Nyholm 1977. Nyholm \& Lyngby 1988). The decrease in the total fractions (TN, TP) which was sometimes observed at the end of the incubation period could have resulted from cell adsorption onto the wall of the incubation flask which was visible 
(a) Phaeodactylum tricornutum (new culture)

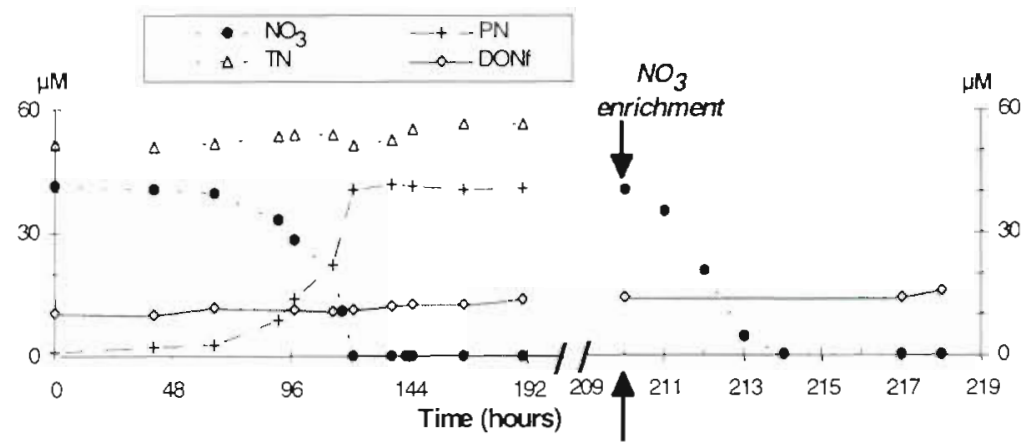

(b) Dunaliella tertiolecta (culture 1)

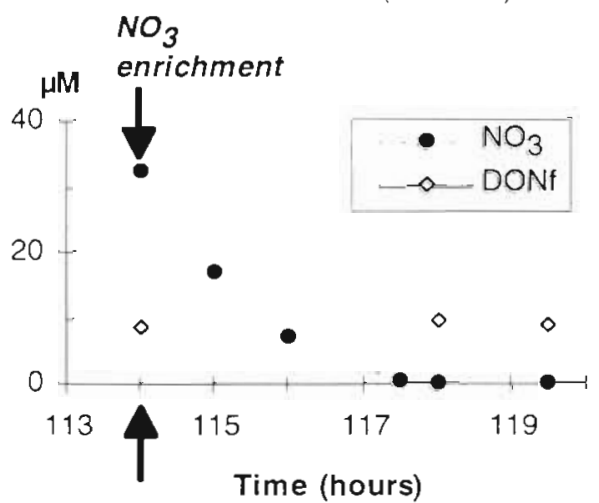

(c) Cultures A, B, C, D and E
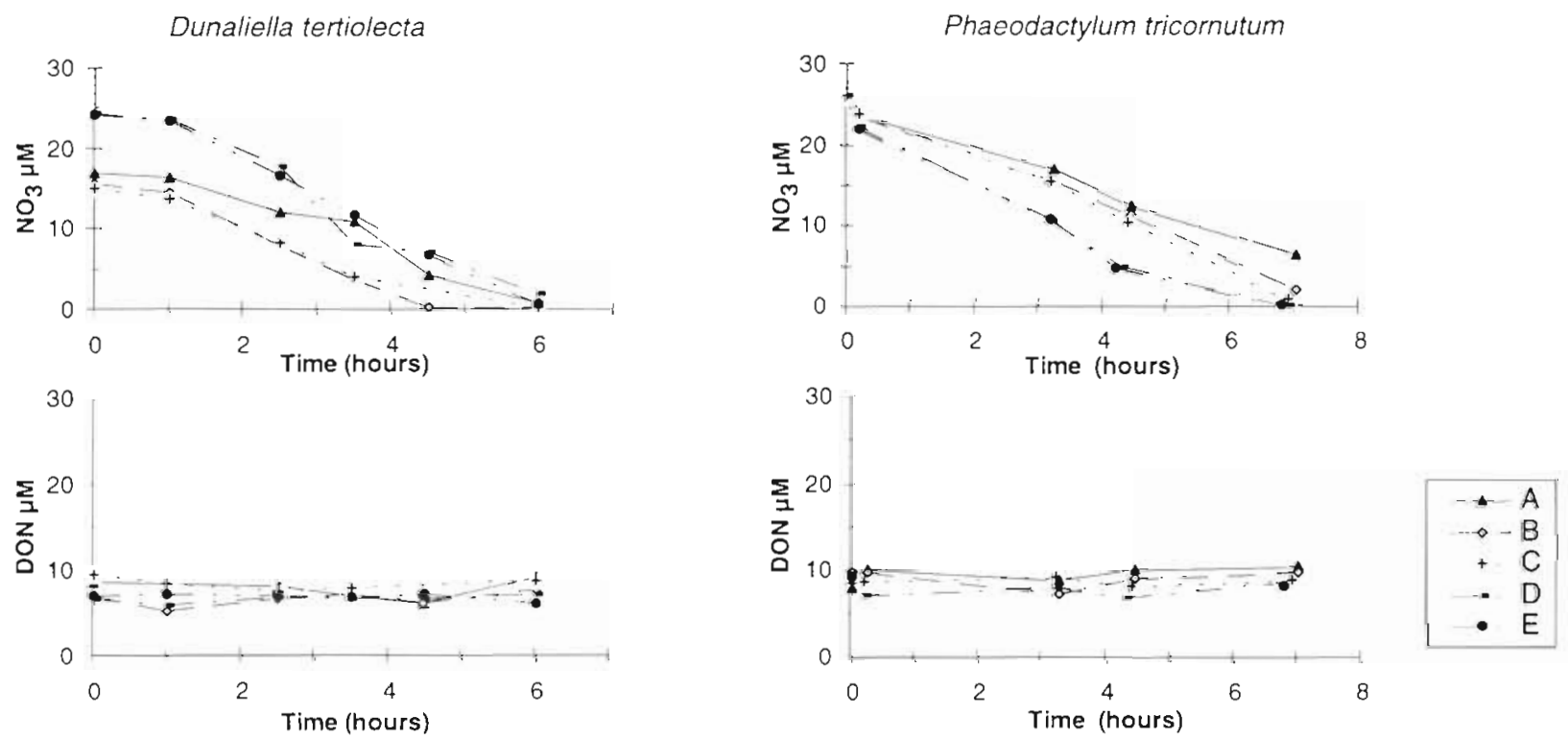

Fig. 2. $\mathrm{NO}_{3}$ uptake and time course of DON concentrations in the cultures during the 'perturbation experiment' (a) New culture of Phaeodactylum tricornutum, (b) culture 1 of Dunaliella tertiolecta, (c) cultures A, B, C, D and E of D. tertiolecta and P. tricornutum. Data from the time period before the nitrate enrichment was made are shown in this figure for the new culture (a); they are shown in Fig. 1 for culture 1 . DON concentrations in cultures $A, B, C, D$ and $E$ before the nitrate enrichment was made are shown in Table 5 . For these cultures, $t=0$ on the $\mathrm{x}$-axis is the time when $\mathrm{NO}_{3}$ enrichment was made

despite constant stirring of the culture. Losses of particulate nitrogen and phosphorus, as well as a decrease in the total fraction, have also been observed during more complex cultures (Andersen et al. 1986) and are often associated with organism adsorption to the bottle wall or due to non-homogeneous sampling (Goldman et al. 1985)

The N/P ratio of 5 to $7.5\left(0.02\right.$ to $0.03 \mathrm{pmol}^{\mathrm{PN}} \mathrm{cell}^{-1}$ and $0.004 \mathrm{pmol}^{\mathrm{PP}} \mathrm{cell}^{-1}$ for Phaeodactylum tricornutum and $0.03 \mathrm{pmol}^{\mathrm{PN}}$ cell ${ }^{-1}$ and $0.03 \mathrm{pmol} \mathrm{PP} \mathrm{cell}^{-1}$ for Dunaliella tertiolecta) in the particulate material has generally been found in cultures to be less than the accepted value for the composition of seawater of 15 or
16:1 (Parsons et al. 1961, Corner \& Davies 1971). Under $\mathrm{N}$ limitation, this $\mathrm{N} / \mathrm{P}$ ratio is typically lower, due to the decreased N/cell (Harrison et al. 1977). In chemostat cultures, this decrease can be as high as 3-fold, from 15 to 5 (Harrison et al. 1976, Perry 1976). This low N/P ratio could also be explained by the capacity of algal cells to accumulate some phosphate into their cytoplasm in excess of their immediate needs (Bonin 1988).

At the end of the cell growth of the culture enriched with labelled nitrate (culture 15-N), nitrogen budgets could be established both from measurements obtained with the wet chemical oxidation method and the isotopic technique, which helps to support the results, 
Table 7 Comparison of DON concentrations between samples coming from inside a sampling bag placed into the culture (DON1) and samples coming from outside this sampling bag and filtered though GF/F filters (DON2). n: no. of observations; df1. degrees of freedom for the F-test (test of the equality of variances as $n<30$ ); and df 2 : degrees of freedom for the $t$-test (equality of means, performed on samples with variances not statistically different). The values of both tests are given and the critical value of the test is indicated in bracket $(v)$. Both tests are nonsignificant $(\alpha=0.05)$, thus DON1 and DON2 are considered identical

\begin{tabular}{|lcc|}
\hline & DON1 & DON2 \\
\hline Mean & 9.83 & 9.56 \\
Variance & 5.75 & 5.62 \\
$\mathrm{n}$ & 12 & 12 \\
$\mathrm{df1}$ & 11 & 11 \\
F-test $(v)$ & \multicolumn{2}{c|}{$1.023(2.818)$} \\
Probability & \multicolumn{3}{c}{0.485} \\
Pooled variance & \multicolumn{3}{c}{5.68} \\
df2 & \multicolumn{3}{c}{22} \\
$t$-test (v) & \multicolumn{3}{c}{$0.278(1.717)$} \\
Probability & \multicolumn{3}{c}{0.392} \\
\end{tabular}

especially those concerning the mean level of the phytoplanktonic DON release. Although the isotopic method is certainly more precise, both nitrogen budgets were very close and show that the quantity of DON released remains low, approximately $4 \%$ of the $\mathrm{NO}_{3}$ uptake. In this culture, the rate of DON release during light/dark incubations was around 10.4 to $13.3 \mathrm{nmol} \mathrm{N} \mathrm{l}^{-1} \mathrm{~h}^{-1}$ (filtered and nonfiltered samples) between the beginning and the end of the experiment. These concentrations of DON excretion enabled us to completely or nearly completely balance the nitrogen budgets in our experiments. Since the cultures remained axenic during the entire experiments, we can be certain that DON produced by the phytoplankton was not immediately taken up by bacteria, as in the case of the natural environment (Nalewajko \& Schindler 1976, Jensen 1983) Furthermore, since no heterotroph was present, these released compounds must have been produced by the phytoplankton via excretion, death and lysis or virus-induced lysis (Suttle et al. 1990, Bratbak et al. 1992). For example, we observed an increase in DON concentrations of up to $15 \mu \mathrm{M}$ in a culture of Dunaliella tertiolecta after we left the culture in senescent conditions for $15 \mathrm{~d}$ (data not shown). Sharp (1977) and Wood et al. (1992) have also observed that a larger percentage of phytoplanktonic production was converted to dissolved organic matter by senescent cells. These observations are in agreement with studies of the relationship between phytoplankton and bacteria indicating that, generally, the flux (through dissolved organic matter) of primary producers towards bacteria is weak (P. Conan, C. M. Tur- ley, E. Stutt, M. Pujo-Pay \& F. Van Wambeke unpubl.). These authors have shown an increase in this flux in relation with a drastic decrease of the assimilation number (Parsons et al. 1984) which characterizes the physiological state of the autotrophic population. Such a decrease may occur during post bloom situations (cell degradation, high rate of grazing, etc.) or because of high cell concentrations during experiments. Nevertheless, looking at the shape of the growth curves, we can say that during the time of the present experiments algal populations were in an active growth phase, and that cellular senescence was a minor contribution to DON release in the culture media.

Concerning active excretion, it has been debated for many years whether phytoplankton can excrete DON during its metabolism (Sharp 1977, Aaronson 1978, Lancelot 1983, Obernosterer \& Herndl 1995). The controversy concerns methodological issues and artefacts (Sharp 1977, 1984, Fuhrman \& Bell 1985) such as the release of DON by cell breakage during filtration (Arthur \& Rigler 1967, Herbland 1974, Goldman \& Dennett 1985) or other experimental shocks (light, temperature, salinity, mechanical shocks, etc.). It has been effectively reported that stressed algae may use this excretion as a mechanism for maintaining metabolic integrity in a changing environment (Fogg et al. 1965, Fogg 1977, 1983, Wood \& Van Valen 1990). However, if mechanical cell breakage during filtration was taking place, it was negligible in the results presented here, since a culture test, conducted with measurements using a 'sampling-bag' did not reveal different DON values compared with those of samples filtered onto GF/F. This observation is important for interpretations of both PN and DON evolution. If filtration can potentially induce an 'artificial' release of DON, this also results in an underestimation of the particulate fraction (PN) determined by the filtration of samples. The level of DON production observed in these growing cultures appears to represent a real process and not an experimental artefact generated by filtration. Furthermore, even when cells were physiologically stressed, niether Phaeodactylum tricornutum nor Dunaliella tertiolecta excreted more DON. No significant 'overflow' reaction of the phytoplankton (Fogg 1983) was observed here due to nutrient deficiency, as has sometimes been reported from laboratory cultures (Myklestad 1977. Watanabe 1980). Here we assume that only $\mathrm{NO}_{3}$ was used as a nitrogen substrate and thus contributed to DON release. In all the cultures we studied, release/excretion of DON remained at less than $6 \%$ of the DIN uptake.

Our results are lower than those previously described (Newell et al. 1972) where the percentage of DIN uptake released as DON was in the range of 7 to $25 \%$ for laboratory cultures of Dunaliella tertiolecta. 
Furthermore, we did not find the high levels of DON release observed by Collos (1992) and Collos et al. (1992) which were up to $63 \%$ of DIN uptake. Neither did we obtain the depletion of DON concentrations around $O \mu \mathrm{M}$ observed in the culture medium after a darkness period reported by Collos et al. (1992). It is possible that the initial nitrate enrichment (around 200 $\mu \mathrm{M})$ produced in their culture created a greater perturbation than we achieved in our cultures (between 15 and $40 \mu \mathrm{M}$ ). In addition, cell rupture during filtration may have occurred in these authors' cultures, where according to the initial cell. concentrations $\left(4 \times 10^{5}\right.$ cells $\mathrm{ml}^{-1}$ ) the biomass was far higher than in the cultures presented here (initial cell concentrations around 1000 or 5000 cells $\mathrm{ml}^{-1}$ ).

Other studies have been carried out on nitrogen uptake by phytoplankton and subsequent release of DON during investigations using the isotopic ${ }^{15} \mathrm{~N}$ technique of Bronk \& Glibert (1991). Estimations by Bronk \& Glibert (1991) and Bronk et al. (1994) were also higher than our results, where an average of 25 to $41 \%$ of DIN taken up by phytoplankton was released as DON. However, their experimental strategy was quite different and experiments were conducted in nonaxenic seawater incubations. Here, $\mathrm{DO} \mathrm{O}^{15} \mathrm{~N}$ was released from phytoplankton or other cells which became labelled with ${ }^{15} \mathrm{~N}$ during the course of the incubation. Furthermore, contrary to previous thinking (Chan \& Campbell 1978, Wheeler \& Kirchman 1986), nitrate uptake by marine bacteria can be significant (Kirchman et al. 1991, 1992, 1994, Pujo-Pay 1995). As some bacteria can pass through $0.2 \mu \mathrm{m}$ filters (Li 1990 , Stockner et al. 1990), nitrate uptake could have resulted from ${ }^{15} \mathrm{~N}$ enrichment associated with these bacteria in the $<0.2 \mu \mathrm{m}$ filtrate thus resulting in an overestimate of DON release (Bronk \& Glibert 1991) On the other hand, in the study by Bronk \& Glibert (1991), higher DON release was found in an experiment conducted during the end of the spring bloom, when there was a rapid decline in the population of phytoplankton. These observations are consistent with our high level of DON release measured in a 'dying' culture of Dunaliella tertiolecta as indicated previously. Other investigations of DON release have been conducted by Glibert \& Bronk (1994) on cyanobacteria. In tropical and sub-tropical oceanic waters, even though an average rate of $50 \%$ of the $N_{2}$ fixed was released as DON during studies on Trichodesmium spp., compared with ambient seawater concentrations of DON, these releases are small (Glibert \& Bronk 1994). Furthermore, in these studies conducted on unfiltered seawater, impact of grazers could not have been estimated. Zooplankton can lead to significant dissolved organic matter (such as amino acids) production (Andersson et al. 1985, Nagata \& Kirchman 1991) and it was likely that they contributed to measured DON release (Glibert \& Bronk 1994).

Finally, levels of DON excretion found in our cultures $(<10 \%)$ are close to those of dissolved organic carbon (DOC) found in the literature. The percentage of primary production excreted as DOC by different phytoplanktonic cultures has been measured to be on average 13\% (Baines \& Paces 1991) or to comprise between 4 and $5 \%$ (Malinsky-Rushansky \& Legrand 1996 ) or 1 to $15 \%$ (see Table 1 in Malinsky-Rushansky \& Legrand 1996). It is notable that these percentages of DOC and our DON release are close to each other and are consistent with the hypothesis that algae maintain a relatively constant $\mathrm{C} / \mathrm{N}$ ratio (Redfield 1958) Later variations in the $\mathrm{C} / \mathrm{N}$ ratio in the dissolved organic matter ( $>100$ ) might be attributed to the different turnover of these 2 elements (Thingstad 1993. Thingstad \& Rassoulzadegan 1995).

Active release of DON by phytoplankton by excretion exists and must be considered within the nitrogen budget. It was, however, relatively low (less than 10\% of the $\mathrm{NO}_{3}$ uptake), at least for Dunaliella tertiolecta and Phaeodactylum tricornutum species, and was not as high as some previous estimates. We have taken care to ensure that stress induced DON release is not incorporated into these estimates. It therefore seems likely that if natural population of phytoplankton excrete DON at similar rates, the contribution from other parts of the plankton community (bacteria, zooplankton, etc.) to DON production (e.g. through protozoan and mesozooplankton grazing, phytoplankton cell death, or virus infections) might explain the high levels of DON release sometimes observed during experimental studies or in the natural environment. If, therefore, DON of phytoplankton origin constitutes a rapidly turned over and easily assimilable pool (Sharp 1977, Cole et al. 1982, Azam et al. 1983) which acts as an important resource for heterotrophic organisms and especially for bacteria (Cole et al. 1982, Azam et al. 1983, Azam et al. 1990), not only excreted compounds should be considered. An estimation of the turnover of the DON released through different ways could be very important in understanding the role of DON in biogeochemical cycles. This could help to clarify the topical hypothesies concerning the importance of DON, especially in oligotrophic areas where this pool comprises the most important fraction of the total nitrogen and where inorganic forms are deficient.

Acknowledgements. We thank F. Van. Wambeke for analyses of samples by epifluorescence microscopy, N. Garcia for her technical assistance throughout the spectrometer analyses, and $\mathrm{M}$. C. Bonin for contributing data from the literature. We particularly and sincerely thank $C$. Turley for her critical reading and helpful comments and discussion during the preparation of this paper 


\section{LITERATURE CITED}

Aaronson S (1978) Excretion of organic matter by phytoplankton in vitro. Limnol Oceanogr 23:838

Andersen OK, Goldman JC, Caron DA, Dennett MR (1986) Nutrient cycling in a microflagellate food chain: III. Phosphorus dynamics. Mar Ecol Prog Ser 31:47-55

Andersson A, Lee C, Azam F, Hagstrom $\AA$ (1985) Release of amino acids and inorganic nutrients by heterotrophic marine microflagellates. Mar Ecol Prog Ser 23:99-106

Antia NJ, Harrison PJ, Oliveira L (1991) The role of dissolved organic nitrogen in phytoplankton nutrition, cell bıology and ecology. Phycologia 30:1-89

Arthur CR, Rigler $H$ (1967) A possible source of error in the $\mathrm{C}^{14}$ method of measuring primary productivity. Limnol Oceanogr 12:121-214

Azam F, Cho BC. Smith DC, Simon M (1990) Bacterial cycling of matter in the pelagic zone of aquatic ecosystem. In: Tilzer MM. Serruya C (eds) Large lakes-ecological structure and function. Springer-Verlag, Berlin, p 477-488

Azam F, Fenchel T, Field JG, Gray JS, Meyer-Reil LA, Thingstad $F$ (1983) The ecological role of water-column microbes in the sea. Mar Ecol Prog Ser 10:257-263

Baines SB, Paces ML (1991) The production of dissolved organic matter by phytoplankton and its importance to bacteria: patterns accoss marine and freshwater systems. Limnol Oceanogr 36:1078-1090

Berland BR, Bonin DJ, Maestrini SY (1980) Azote ou phosphore? Considérations sur le 'paradoxe nutritionnel' de la mer Méditerranée. Oceanologica Acta 3:135-142

Bohlin K (1897) Zur Morphologie und Biologie einzelliger Algen. Ofvers Forh Kongl Svenska Vetensk-Akad 9: 507-529

Bonin (1988) Role du phosphore organique dissous dans la production primaire. Oceanıs 14(2):381-387

Bratbak G, Heldal M. Thingstad TF, Riemann B, Haslund OH (1992) Incorporation of viruses into the budget of microbial C-transfer. A first approach. Mar Ecol Prog Ser 86: $273-280$

Bronk DA, Glibert PM (1991) A ${ }^{15} \mathrm{~N}$ tracer method for the measurement of dissolved organic nitrogen release by phytoplankton. Mar Ecol Prog Ser 77:171-182

Bronk DA, Glibert PM (1993) Application of a ${ }^{15} \mathrm{~N}$ tracer method to the study of dissolved organic nitrogen uptake during spring and summer in Chesapeake Bay. Mar Biol 115:501-508

Bronk DA, Glibert PM (1994) The fate of the missing ${ }^{15} \mathrm{~N}$ differs among marine systems. Limnol Oceanogr 39(1): 189-195

Bronk DA, Glibert PM, Ward BB (1994) Nitrogen uptake, dissolved organic nitrogen release, and new production. Science 265:1843-1846

Butcher RW (1952) Contributions to our knowledge of the smaller marine algae. J Mar Biol Assoc UK 31:175-191

Chan YK, Campbell NER (1978) Phytoplankton uptake and excretion of assimilate nitrate in a small Canadian shield lake. Appl Environ Microbiol 35:1052-1060

Codispotı LA (1989) Phosphorus versus nitrogen limitation of new and export production. In: Berger WH, Smetacek VS, Wefer G (eds) Productivity of the ocean: present and past. $J$ Wiley and Sons, Chichester, p 377-394

Cole JJ, Likens GE, Strayer DL (1982) Photosynthetically produced dissolved organic carbon: an important source for planktonic bacteria. Limnol Oceanogr 27:1080-1090

Collos Y (1986) Time-lag algal growth dynamics: biological constraints on primary production in aquatic environments. Mar Ecol Prog Ser 33:193-206
Collos Y (1992) Nitrogen budgets and dissolved organic matter cycling. Mar Ecol Prog Ser 90:201-206

Collos Y, Döhler G, Biermann I (1992) Production of dissolved organic nitrogen during uptake of nitrate by Synedra planctonica: implications for estimates of new production in the oceans. J Plankton Res 14:1025-1029

Corner EDS, Davies AG (1971) Plankton as a factor in the nitrogen and phosphorus cycles in the sea. Adv Mar Biol 9 101-204

Droop MR (1974) The nutrient status of algal cells in continucus culture. J Mar Biol Assoc UK 54:825-855

Duarte CM (1990) Time-lag in algal growth: generality, causes and consequences. J Plankton Res 12:873-883

Eppley RW, Peterson BJ (1979) Particulate organic matter and planktonic new production in deep ocean. Nature 282 $311-323$

Eppley RW, Renger EH, Venrick EL, Mullin MN (1973) A study of plankton dynamics and nutrient cycling in the central gyre of the North Pacific Ocean. Limnol Oceanogr 18:534-551

Fogg GE (1965) Algal culture and phytoplankton ecology. University of Wisconsin Press, Madison

Fogg GE (1977) Excretion of organic matter by phytoplankton. Limnol Oceanogr 22:576-577

Fogg GE (1983) The ecological significance of extracellular products of phytoplankton photosynthesis. Bot Mar 26: 3- 14

Fogg GE, Nalewajko G, Watt WD (1965) Extracellular products of phytoplankton photosynthesis. Proc R Soc Lond B $162: 517-534$

Fuhrman J (1987) Close coupling between release and uptake of dissolved free ammo acids in seawater studied by an 1sotope dilution approach. Mar Ecol Prog Ser 37:45-52

Fuhrman JA, Bell TM (1985) Brological considerations in the measurement of dissolved free amino acids in seawater and implications for chemical and microbiological studies. Mar Ecol Prog Ser 25:13-21

Glibert PM, Bronk DA (1994) Release of dissolved organic nitrogen by marine diazotrophic cyanobacteria, Trichocesmium spp. Appl Environ Microbiol 60(11):3996-4000

Goldman JC, Caron DA, Andersen OK, Dennett MR (1985) Nutrient cycling in a microflagellate food chain: 1. Nitrogen dynamics. Mar Ecol Prog Ser 24:231-242

Goldman JC, Dennett MR (1985) Susceptibility of some marne phytoplankton species to cell breakage during filtration and post-filtration rinsing. J Exp Mar Biol Ecol 86 $47-58$

Golcman JC, MCCarthy JJ, Peavey DG (1979) Growth rate influence on the chemical composition of phytoplankton in oceanic waters. Nature 279:210-215

Grenney WJ, Bella DA, Curl HC (1973) A theoretical approach to interspecific competition in phytoplankton communities. Am Net 107:405-425

Guillard RRL, Ryther JH (1962) Studies of marine planktonic diatoms. I. Cyclotella nana (Hustedt) and Detonula confervacea (Cleve) Gran. Can J Microbiol 8:229-239

Hansell DA, Goering JJ (1989) A method for estimating uptake and production rates for urea in seawater using $\int^{14} \mathrm{C}$ Jurea and $\left.\right|^{15} \mathrm{C}$ Jurea. Can J Fish Aquat Sci 46:198-202

Harrison PJ, Conway HL, Dugdale RC (1976) Marine diatoms grown in chemostats under silicate or ammonium limitation. 1. Cellular chemical composition and steady-state growth kinetics of Skeletonema costatum. Mar Biol 35: $177-186$

Harrison PJ, Conway HL, Holmes RW, Davis CO (1977) Marine diatoms in chemostats under silicate or ammonium lumitation. III. Cellular chemical composition and morphol- 
ogy of Chaetoceros debilis, Skeletonema costatum, and Thalassiosira gravida. Mar Biol 43:19-31

Hedges JI, Bergamaschi BA, Benner R (1993) Comparative analyses of DOC and DON in natural waters. Mar Chem 41:121-134

Herbland A (1974) Influence de la dépression de filtration sur la mesure simultanée de l'assimilation et de l'excrétion organique du phytoplancton. Cah ORSTOM Sér Océanogr 12:173-174

Howarth RW, Cole JJ (1985) Molybdenum availability, nitrogen lumitation, and phytoplankton growth in natural waters. Science 229:653-655

Jensen LM (1983) Phytoplankton release of extracellular organic carbon, molecular welght composition, and bacterial assimilation. Mar Ecol Prog Ser 11:39-48

Jorgensen NOG, Kroer N, Coffin RB, Yang XH, Lee C (1993) Dissolved free amino acids, combined amino acids, and DNA as sources of carbon and nitrogen to marine bacteria Mar Ecol Prog Ser 98:135-148

Kirchman DL, Ducklow HW, MCCarthy JJ, Garside C (1994) Biomass and nitrogen uptake by heterotrophic bacteria during the spring phytoplanktonic bloom in the North Atlantic Ocean. Deep Sea Res 41(5-6):879-895

Kirchman DL, Moss J, Keil RG (1992) Nitrate uptake by heterotrophic bacteria: does it change the f-ratio? Arch Hydrobiol Beih Ergeb Limnol 37:129-138

Kirchman DL, Suzuki Y, Garside C, Ducklow HW (1991) High turnover rates of dissolved arganic carbon duning a spring phytoplankton bloom. Nature 352:612-614

Kofoid CA (1903) The plankton of the Illinois River 1894-1899, with introductory notes upon the hydrography of the Illinois River and its basin. Part 1. Quantitative investigations and general results. Bull Illinois State Lab Nat Hist 6:95-629

Koroleff F (1969) Direct determination of ammonia in natural waters as indophenol blue. Comm Meet Int Counc Explor Sea CM-ICES/C:9

Lancelot C (1983) Factors affecting phytoplankton extracellular release in the southern bight of the North Sea. Mar Ecol Prog Ser 12:11.5-121

Laws E (1984) Isotope dilution models and the mystery of the vanishing ${ }^{15} \mathrm{~N}$. Limnol Oceanogr 29:379-386

Li WKW (1990) Particles in 'particles-free' seawater growth of ultraphytoplankton and implications for dilution experiments. Can J Fish Aquat Sci 47:1258-1268

Malinsky-Rushansky NZ, Legrand C (1996) Excretion of dissolved organic carbon by phytoplankton of different sizes and subsequent bacterial uptake. Mar Ecol Prog Ser 132 $249-255$

McCarthy JJ, Taylor WR, Taft JL (1977) Nitrogenous nutrition of the plankton in the Chesapeake Bay. I. Nutrient availability and phytoplankton preferences. Limnol Oceanogr $22: 996-1011$

Myklestad S (1977) Production of carbohydrates by manne planktonic diatoms. II. Influence of the N/P ratio in the growth medium on the assimilation ratio, growth rate, and production of cellular and extracellular carbohydrates by Chaetoceros affinis var. willei (Gran) Hustedt and Skeletonema costatum (Grev) Cleve. J Exp Mar Biol Ecol 29: $161-179$

Nagata T, Kirchman DL (1991\} Release of dissolved free and combined amino acids by bacterivorous marine flagellates. Limnol Oceanogr 36:433-443

Nalewajko C. Schindler DW (1976) Primary production, extracellular release, and heterotrophy in two lakes in the ELA, northwestern Ontario. J Fish Res Bd Can 33: $219-226$
Newell BS, Dalpont G, Grant BR (1972) The excretion of organic nitrogen by marine algae in batch and continuous culture. Can J Bot 50:2605-2611

Nyholm N (1977) Kinetics of nitrogen-limited algal growth Prog Wat Technol 8:347-358

Nyholm N, Lyngby JE (1988) Algal bioassays in eutrophication research-discussion in the framework of a mathematical analysis. Water Res 22:1293-1300

Obernosterer I, Herndl GJ (1995) Phytoplankton extracellular release and bacterial growth: dependence on the nnorganic N/P ratio. Mar Ecol Prog Ser 116:247-257

Parsons TR, Stephens K, Strickland JDH (1961) On the chemical composition of eleven species of marne phytopankters. J Fish Res Bd Can 18:1001-1016

Parsons TR, Takahashi M. Hargave B (1984) Biological oceanic processes, 3rd edn. Pergamon Press, Oxford

Paul JH, Jeffrey WH, DeFlaun MF (1987) Dynamics of extracellular DNA in the marine environment. Appl Environ Microbiol 53:170-179

Perry MJ (1976) Phosphate utilization by an oceanic diatom in phosphorus-limited chemostat culture and in the oligotrophic waters of the central north Pacific. Limnol Oceanogr 21:88-107

Pujo-Pay M (1995) L'azote et le phosphore en milieu marin. Importance des formes organiques dissoutes en milieu océanique du large. Thèse Doct Univ Aix-Marseille II

Pujo-Pay M, Raimbault P (1994) Improvement of the wet-oxidation procedure for similtaneous determination of particulate organic nitrogen and phosphorus collected on filters. Mar Ecol Prog Ser 105:203-207

Redfield AC (1958) The biological control of the chemical factors in the environment. Am Sct 46:205-222

Ryther JH, Dunstan WM (1971) Nitrogen, phosphorus and eutrophication in the coastal marine environment. Science 171:1008-1013

Sharp JH (1977) Excretion of organic matter by marine phytoplankton: do healthy cells do it? Limnol Oceanogr 22: 281-299

Sharp JH (1983) The distributions of inorganic nitrogen and dissolved and particulate organic nitrogen in the sea. In: Carpenter EJ, Capone DG (eds) Nitrogen in the marine environment. Academic Press, New York, p 1-35

Sharp JH (1984) Inputs into microbial food chains. In: Hobbie JE, Williams PJ LeB (eds) Heterotrophic actinity in the sea. NATO Conterences Series IV, Plenum Press, New York, p $1.01-120$

Sharp JH (1993) The dissolved organic carbon controversy: an update. Oceanography 6:45- 50

Slawyk G, Raimbault P (1995) A simple procedure for simultaneous recovery of dissolved inorganic and dissolved organic nutrogen in ${ }^{15} \mathrm{~N}$-tracer experiments on oceanic waters improving mass balance. Mar Ecol Prog Ser 124: $289-299$

Slawyk G, Raimbault P. Gentilhomme V (1990) On the discrepancies between a colorimetric and 1sotopic method for measuring nitrate utilisation in nitrate-depleted waters: implication for the design of experimental protocols in new production stdies. Hydrobiol 207:333-339

Storkner JG, Klut ME, Cochlan WP (1990) Leaky filters: a warning to aquatic ecologists. Can J Fish Aquat Sci 47:16-23

Suttle CA, Chan AM, Cottrell MT (1990) Infection of phytoplankton by viruses and reduction of primary production. Nature 347:467-469

Thingstad TF (1993) Microbial processes and the biological carbon pump. In: Evans GT, Fasham MJR (eds) Towards a model of ocean biogeochemical processes. SpringerVerlag, Berlin, p 193-208 
Thingstad TF, Rassoulzadegan F (1995) Nutrient limitations, microbial food webs, and 'biological C-pumps': suggested interactions in a P-limited Mediterranean. Mar Ecol Prog Ser 117:299-306

Thomas WH (1966) Surface nitrogenous nutrients and phytoplankton in the northeastern tropical Pacific Ocean. Limnol Oceanogr 11:393-400

Tréguer P, Le Corre P (1975) Manuel d'analyses des sels nutritifs dans l'eau de mer. Laboratoire d' Océanographie Chimique. Université de Bretagne Occidentale, Brest

Turley CM (1985) Biological studies in the vicinity of a shallow-sea tidal mixing front IV. Seasonal and spatial distribution of urea and its uptake by phytoplankton. Phil Trans R Soc Lond B 310:471-500

Turley CM (1986) Urea uptake by phytoplankton at different fronts and associated stratified and mixed waters on the european shelf. Br Phycol J 21:225-238

This article was presented by A. Bianchi, Marseille, France
Van Wambeke F (1988) Numération et taille des bactéries planctoniques au moyen de l'analyse d'images couplée à l'épifluorescence. Ann Inst Pasteur Microbiol 139:261-272

Watanabe $Y(1980)$ A study of the excretion and extracellular products of natural phytoplankton in Lake Nakanuma, Japan. Int Rev Ges Hydrobiol 65:809-834

Wheeler PA, Kirchman DL (1986) Utilization of inorganic and organic nitrogen by bacteria in marine system. Limnol Oceanogr 31:998-1009

Wood AM, Rai H, Garnier J, Kairesalo T, Gresens S, Orive E, Ravail B (1992) Practical approaches to algal excretion. Mar Microb Food Webs 6:21-38

Wood AM, Van Valen LM (1990) Paradox lost? On the excretion of energy-rich compounds by phytoplankton. Mar Microb Food Webs 4:103-116

Yentsch CS, Vaccaro RF (1958) Phytoplankton nitrogen in the oceans. Limnol Oceanogr 3:443-448

Manuscript first received: August 22, 1996

Revised version accepted: May 20, 1997 